FORUM

FORUM

FORUM
FORUM is intended for new ideas or new ways of interpreting existing information. It provides a chance for suggesting hypotheses and for challenging current thinking on ecological issues. A lighter prose, designed to attract readers, will be permitted. Formal research reports, albeit short, will not be accepted, and all contributions should be concise with a relatively short list of references. A summary is not required.

\title{
Parasitism, climate oscillations and the structure of natural communities
}

\author{
Kim N. Mouritsen and Robert Poulin, Dept of Zoology, Univ. of Otago, P.O. Box 56, Dunedin, New Zealand \\ (kim.mouritsen@stonebow.otago.ac.nz).
}

Recently, Ottersen et al. (2001) reviewed the ecological impacts of the North Atlantic climate oscillation (NAO). The NAO is responsible for interannual and decadal fluctuations in winter temperatures, precipitation, wind conditions as well as distribution and fluxes of currents on both sides of the North Atlantic Ocean (Hurrell and van Loon 1997). A highly positive NAO index (measured as the deviance from the average sea level pressure difference between the Azores and Iceland) is associated with high temperatures, strong winds and high levels of precipitation in northern Europe, and low temperatures in eastern North America. A low NAO index gives rise to the opposite conditions (Hurrell and van Loon 1997). The NAO can be seen as a North Atlantic parallel to the El Niño-Southern-Oscillation (ENSO) in the Pacific Ocean also resulting in temporal and geographical fluctuations in temperature and precipitation from the Indian Ocean to the Gulf of Mexico (Allan et al. 1996).

Such large-scale climatic fluctuations are bound to affect a multitude of ecological processes. Indeed, in addition to the direct influence on the general biological performance of various organisms, Ottersen et al. (2001) also report studies demonstrating more complex and indirect cascading effects in which NAO mediates the outcome of interspecific competitive and predatorprey/herbivore-plant interactions. However, despite the mounting evidence that parasites can influence the composition and structure of natural communities (Minchella and Scott 1991, Hudson and Greenman 1998), and that parasite transmission is often strongly affected by weather conditions, there was no mention of parasitism in the review. In the ecological literature, this is not an unusual omission, as several authors have emphasised recently (Mouritsen and Madsen 1994, Huxham et al. 1995, Marcogliese and Cone 1997, Morand and Gonzales 1997, Poulin 1999, Thomas et al. 1999, Skorping and Högstedt 2001). To the authors' defence, their review focused on papers that either investigated the influence of NAO directly or presented time-series that would suggest the signature of this climate oscillation. And to our knowledge, no study has hitherto explicitly considered the impact of NAO on host-parasite interactions.

Nevertheless, examples of ENSO-mediated parasiteinduced host dynamics do exist, and several papers have directly or indirectly shown that parasite-induced host population dynamics or distribution are governed by short-term changes in weather conditions or general climate change (see e.g. Harvell et al. 1999, Marcogliese 2001, and references in Table 1). To us, this clearly justifies specific attention to the potential influence of climate oscillations on host-parasite interactions, host population dynamics, and consequently also on community structure.

Table 1 summarises a range of very different hostparasite systems influenced by temperature in particular, but also by precipitation and ocean currents. Although comprehensive, the list is certainly not exhaustive and only serves to illustrate the potential widespread effect of climate oscillations on parasitism and its consequences.

Although the oscillations will affect the climate almost worldwide throughout the year, they are basically ocean phenomena restricted - in the case of the extratropical oscillations - to the winter season (Allan et al. 1996, Hurrell and van Loon 1997). For this reason, we have focused on host-parasite systems from nearcoastal areas where the winter sea surface temperature may carry over through to the summer (Ottersen et al. 2001), and on parasites having life cycles that will render them sensitive also to the winter and/or early spring climate.

The first examples emphasise the direct impact on the life-cycle processes of the parasites (especially transmission rates) whereas the remaining ones demonstrate more complex cascade effects, in which the outcome of the specific host-parasite interaction is found or 
Table 1. The influence of weather conditions on life-cycle processes of various parasites (general direct effects) and the cascading impact on host population and community dynamics (indirect cascade effects) categorised according to ecosystem/habitat. Numbers refer to case studies dealt with in the text. Indication of climate oscillation (NAO or ENSO) denotes the weather system expected to be relevant according to the geographical location of the case studies. The oscillation-related weather factor indicated in the fourth column has a positive effect on either the associated process in the parasite life cycle or its interaction with the host. $\mathrm{Q}_{10}$ is the generalised 2-fold increase in a given biological process by a temperature increase of $10^{\circ} \mathrm{C}$.

\begin{tabular}{|c|c|c|c|c|c|}
\hline Ecosystem, Habitat & Host & Parasite & $\begin{array}{l}\text { Oscillation, related factor and parasite life-cycle } \\
\text { process }\end{array}$ & $\begin{array}{l}\text { Known or expected level of } \\
\text { impact }\end{array}$ & References \\
\hline \multicolumn{6}{|l|}{ General direct effects } \\
\hline $\begin{array}{l}\text { Marine and } \\
\text { freshwater }\end{array}$ & Molluscs & $\begin{array}{l}\text { Trematodes } \\
\text { (digenean) }\end{array}$ & $\begin{array}{l}\text { NAO/ENSO; high temperatures; temperature- } \\
\text { dependent emergence of larval parasites } \\
\left(>\mathrm{Q}_{10} \text {-effect) }\right.\end{array}$ & Parasite transmission & $\begin{array}{l}\text { Ginetsinskaya (1988), Shostak and } \\
\text { Esch (1990), Lo and Lee (1996), } \\
\text { Lyholt and Buchmann (1996), } \\
\text { Mouritsen and Jensen (1997) }\end{array}$ \\
\hline $\begin{array}{l}\text { Marine and } \\
\text { freshwater }\end{array}$ & Various & $\begin{array}{l}\text { Trematodes } \\
\text { (digenean) }\end{array}$ & $\begin{array}{l}\mathrm{NAO} / \mathrm{ENSO} \text {; high temperatures; } \\
\text { temperature-dependent infectivity of larval } \\
\text { parasites }\end{array}$ & $\begin{array}{l}\text { Parasite transmission and } \\
\text { intensity }\end{array}$ & $\begin{array}{l}\text { Vanoverschelde (1982), Evans (1985), } \\
\text { Pechenik and Fried (1995), McCarthy } \\
\text { (1999) }\end{array}$ \\
\hline $\begin{array}{l}\text { Marine and } \\
\text { freshwater }\end{array}$ & Various & $\begin{array}{l}\text { Trematodes } \\
\text { (digenean) }\end{array}$ & $\begin{array}{l}\text { NAO/ENSO; high temperatures; temperature- } \\
\text { dependent egg and larval development } \\
\left(>\mathrm{Q}_{10} \text {-effect) }\right.\end{array}$ & Parasite transmission & $\begin{array}{l}\text { Erasmus (1972), Pflüger (1980), } \\
\text { Ginetsinskaya (1988), Ataev (1991) }\end{array}$ \\
\hline Freshwater & Fish & Monogeneans & $\begin{array}{l}\text { NAO/ENSO; high temperatures; } \\
\text { temperature-dependent parasite fecundity } \\
\left(>\mathrm{Q}_{10} \text {-effect }\right)\end{array}$ & Parasite transmission & Kearn (1986) \\
\hline Lake & Fish & Cestodes & $\begin{array}{l}\text { NAO/ENSO; low temperature; temperature- } \\
\text { dependent parasite survival }\end{array}$ & Parasite intensity & Anderson (1974) \\
\hline Terrestial & $\begin{array}{l}\text { Birds and } \\
\text { mammals }\end{array}$ & Nematodes & $\begin{array}{l}\mathrm{NAO} / \mathrm{ENSO} \text {; high temperatures and high } \\
\text { levels of precipitation; temperature and } \\
\text { humidity dependent development rate and } \\
\text { survival of free-living larvae }\end{array}$ & Parasite transmission & $\begin{array}{l}\text { Smith and Grenfell (1985), Anderson } \\
\text { (1992) }\end{array}$ \\
\hline Terrestial & various & Ticks & $\begin{array}{l}\text { NAO/ENSO; high temperatures and high levels } \\
\text { of precipitation; temperature and humidity } \\
\text { dependent development rates, survival and } \\
\text { activity }\end{array}$ & $\begin{array}{l}\text { Tick and disease } \\
\text { (microparasite) transmission }\end{array}$ & $\begin{array}{l}\text { Campbell and Glines (1979), Duffy } \\
\text { and Campbell (1994), Zahler and } \\
\text { Gothe (1995), Vail and Smith (1998), } \\
\text { Chilton et al. (2000) }\end{array}$ \\
\hline \multicolumn{6}{|l|}{ Indirect cascade effects } \\
\hline $\begin{array}{l}\text { [1] Marine } \\
\text { soft-bottom } \\
\text { intertidal }\end{array}$ & $\begin{array}{l}\text { Gastropod/ } \\
\text { amphipod }\end{array}$ & $\begin{array}{l}\text { Trematodes } \\
\text { (digenean) }\end{array}$ & $\begin{array}{l}\text { NAO; high spring temperatures; temperature- } \\
\text { dependent parasite-induced host mortality }\end{array}$ & $\begin{array}{l}\text { Host population and } \\
\text { community structure }\end{array}$ & $\begin{array}{l}\text { Jensen and Mouritsen (1992), } \\
\text { Mouritsen et al. (1997, 1998) }\end{array}$ \\
\hline $\begin{array}{l}\text { [2] Marine soft- } \\
\text { bottom intertidal }\end{array}$ & Bivalve & $\begin{array}{l}\text { Trematode } \\
\text { (digenean) }\end{array}$ & $\begin{array}{l}\text { ENSO; high temperatures; temperature- } \\
\text { dependent parasite-transmission }\end{array}$ & $\begin{array}{l}\text { Host population and } \\
\text { community structure }\end{array}$ & $\begin{array}{l}\text { Thomas and Poulin (1998), Thomas } \\
\text { et al. (1998) }\end{array}$ \\
\hline $\begin{array}{l}\text { Marine rocky } \\
\text { intertidal }\end{array}$ & Gastropod & $\begin{array}{l}\text { Trematodes } \\
\text { (digenean) }\end{array}$ & $\begin{array}{l}\text { NAO; high spring and low winter } \\
\text { temperatures; temperature-dependent host } \\
\text { mortality }\end{array}$ & Host population & Huxham et al. (1993) \\
\hline $\begin{array}{l}\text { [3] Marine rocky } \\
\text { subtidal }\end{array}$ & Sea urchin & Amoeba & $\begin{array}{l}\text { NAO; high temperatures and wind generated } \\
\text { coastal currents; temperature and current } \\
\text { dependent host mortality and parasite dispersal }\end{array}$ & $\begin{array}{l}\text { Host population and } \\
\text { community structure }\end{array}$ & Scheibling and Hennigar (1997) \\
\hline $\begin{array}{l}\text { [3] Marine rocky } \\
\text { subtidal }\end{array}$ & Sea urchin & Nematode & $\begin{array}{l}\text { NÄO; high temperatures; temperature- } \\
\text { dependent parasite development }\end{array}$ & $\begin{array}{l}\text { Host population and } \\
\text { community structure }\end{array}$ & Hagen (1995a), Hagen 1995b) \\
\hline Coastal & Corals & E.g. virus & $\begin{array}{l}\text { ENSO; high temperatures; temperature- } \\
\text { dependent parasite outbreak }\end{array}$ & Host population & $\begin{array}{l}\text { Harvell et al. (2001), Wilson et al. } \\
\text { (2001) }\end{array}$ \\
\hline [4] Coastal & Bivalve & Protozoa & $\begin{array}{l}\text { ENSO; high temperatures and low levels of } \\
\text { precipitation; temperature and salinity } \\
\text { dependent parasite development }\end{array}$ & $\begin{array}{l}\text { Host population and } \\
\text { distribution }\end{array}$ & Ford (1996), Kim and Powell (1998) \\
\hline
\end{tabular}




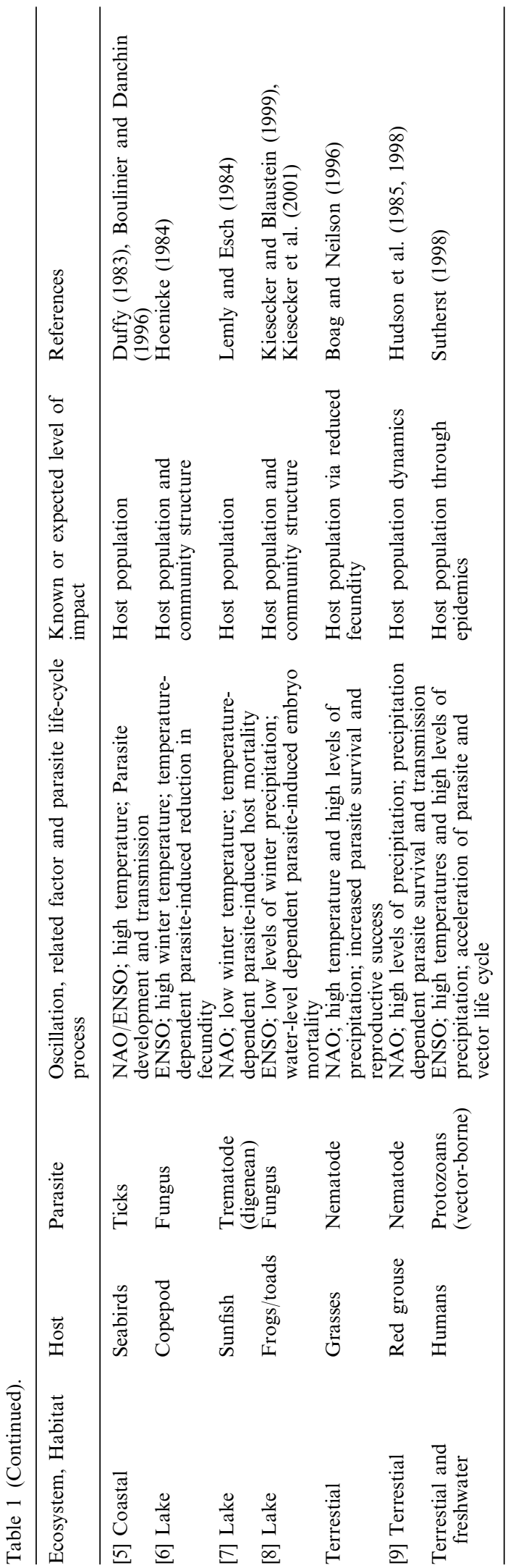

expected to be significantly affected by weather conditions and thereby climate oscillations. Some of the latter will be considered in further detail below, where numbers refer to numbers in Table 1 . References already listed in the table are not given in the following account.

[1] Mud snails (Hydrobia spp.) and corophiid amphipods often co-occur in high densities in coastal areas of northwestern Europe where they act, respectively, as first and second intermediate hosts to a range of microphallid trematodes using shorebirds as final hosts. In the Danish Wadden Sea, a dense population of Corophium volutator vanished completely during a mere five weeks in spring 1990, and the density of the sympatric mud snail Hydrobia ulvae declined by $40 \%$. This was ascribed to microphallid-induced mortality mediated by relatively high spring temperatures, which accelerated both the development rate and the release of infective larval stages from the snails. The disappearance of the amphipods, and of their sediment-stabilising burrows, was followed by substantial sediment erosion and significant changes in the remaining community of benthic invertebrates. Interestingly, the event took place in a period of unusually high NAO indices (see Ottersen et al. 2001), and it may be predicted that microphallid epizootics in coastal amphipod populations are more likely to develop during years characterised by a high NAO index.

[2] The New Zealand cockle Austrovenus stutchburyi is secondary host to an echinostomatid trematode (Curtuteria australis) using whelks and shorebirds as first and final host, respectively. The metacercariae infect only the foot of the cockle rendering heavily infected hosts unable to burrow if dislodged to the sediment surface. Here, the cockles are attacked by the predatory whelks (Ansell 2001) and exposed to a significantly higher predation pressure from shorebirds. Moreover, surface cockles also function as a substrate for limpets that would not exist on the mud flat in their absence. Emergence of cercariae from the snail hosts as well as their infectivity are positive functions of temperature in marine trematodes, including C. australis (Allison 1979, and references in Table 1). Hence, high temperatures are expected to elevate the infection intensity in cockles that may cause a decline in their abundance due to increased predation, as well as a change in the community of epibenthic invertebrates due to immigration of limpets profiting from the presence of surface cockles and shells.

[3] Sea urchins are common components of the rocky subtidal community. In areas where significant predators such as sea otters are absent, their high density and grazing pressure often result in the disappearance of kelp forests. However, along the American northeast coast, the sea urchin Strongylocentrotus droebachiensis is host to a parasitic amoeba (Paramoeba invadens) that regularly eradicates the host population. Such epizootics result in major changes in the subtidal community as areas previously occupied by grazing sea urchins are 
re-colonised by kelp and its associated community. The development and transmission rate of $P$. invadens increase exponentially with temperature, and the distributional range of the parasite is determined by coastal currents. Accordingly, epizootic outbreaks of paramoebiasis are found to be associated with both unusually high sea surface temperatures and storm activity; the latter affects the coastal currents. The occurrence of these meteorological phenomena is related to NAO (Ottersen et al. 2001).

A similar system of alternating dominance of sea urchins (same species) and kelp forests exists along the west coast of Norway. Here, the sea urchins are hosts to a directly transmitted mermithoid nematode (Echinomermella matsi) that frequently wipes out the sea urchin population, an event followed by the recovery of the kelp forest community. So far, these (irregular) cycles have not been directly related to climatic conditions, but NAO can easily be envisaged to play a significant role in the severity of Echinomermella outbreaks: the development rate of parasitic nematodes in their aquatic poikilotherm hosts is a positive function of temperature (Chubb 1980, 1982, De et al. 1986), and Echinomermella larvae may very well be dispersed by currents. In western Norway, the impact of NAO on the climate is particularly strong and it is notable that the observed transition from sea urchin dominated barren ground to immature kelp forest at several Norwegian localities during the mid 1980s, coincided with high NAO indices (see Ottersen et al. 2001).

[4] The parasitic protozoan Perkinsus marinus is widespread in oyster populations (Crassostrea virginica) ranging from the Gulf of Mexico to Chesapeake Bay (Virginia, USA), and gives rise regularly to epizootic-like host mortalities. The development rate of this protozoan is strongly (positively) related to sea temperature and salinity and the infection intensities in the Gulf of Mexico as well as the parasites' geographical distribution seem directly related to ENSO and global warming in general. Hence, the climate oscillations' impact on the population dynamics of oysters appears largely mediated by parasites.

[5] Ticks are common parasites of seabirds, and may significantly depress population densities through reduced breeding success, direct intensity-dependent mortality or, indirectly, as vectors for pathogenic microparasites such as viruses and spirochaetes. In colonies of Peruvian seabirds, the tendency of nest and chick desertion was strongly correlated with tick abundance, and a reanalysis of the Peruvian data suggests that the proportion of breeding birds that abandon the colony is on average higher during El Niño years (40.7\%) than during other years (14.4\%). Whereas nest desertion seems unrelated to the negative impact ENSO may have on the coastal fish-stocks exploited by the birds, the climate oscillation might well act through the significant influence of temperature and humidity on the reproduc- tion, development rate, survival and activity of parasitic ticks. Correlations between climate and tick dynamics as well as their activity have previously been demonstrated (Miscevic et al. 1989, Korotkov 1998, Lindgren et al. 2000).

In the northeast Atlantic, ticks have also been shown to affect the breeding populations of kittiwakes (Rissa tridactyla) negatively. Although weather conditions may affect the survival rate of seabirds in several ways unrelated to parasites, the NAO could partly mediate such population trends through its impact on parasite abundance and activity.

[6] The calanoid copepod Diaptomus novamexicanus is competitively superior to other members of the zooplankton community in a Californian lake. However, D. novamexicanus is parasitised by a fungus (Phycomycetes) that destroys the copepod's eggs. The successful establishment of the fungal infection appears strongly temperature-dependent and is therefore likely to be affected by climate oscillations. Low spring temperatures following a cold winter allow the copepod eggs to hatch before the fungus manages to spread through the host population. After mild winters, in contrast, the infestation develops to epizootic proportions before hatching occurs, which causes the $D$. novamexicanus population to collapse. Released from their dominant competitor, the abundance of other pelagic crustaceans increases, changing the entire structure of the zooplankton community.

[7] In northeastern American lakes, bluegill sunfish Lepomis macrochirus are often heavily infected by metacercariae of the trematode Uvulifer ambloplitis that cause 'blackspot' disease. Because the condition factor of the sunfish is a negative function of infection intensity, and because the fish do not feed during winter, heavily infected individuals are particularly likely to die from their infection before the arrival of spring. So, a substantially larger part of the sunfish population may die-off during cold winters (which are associated with a high NAO index in this region) than during warmer winters.

[8] In the Pacific Northwest of the United States (Oregon) the populations of amphibians (frogs and toads) have declined in resent decades due to increased embryo mortality. Whereas the pathogenic oomycete Saprolegnia ferax (water mold) has been identified as the ultimate mortality agent, the embryo's vulnerability to infection is positively related to UV-B exposure. The flux of UV-B radiation is a negative function of water depth at the oviposition sites, which in turn is determined by winter precipitation in the area. Since the level of precipitation in Oregon itself is a positive function of the southern oscillation index (SOI), the ENSO hence controls the population dynamics of certain amphibians through its impact on parasite outbreaks.

These circumstances may also affect the structure of the local amphibian community. The Pacific treefrog Hyla regilla is usually competitively inferior to the 
Cascades frog Rana cascadae, the latter has strong negative effects on the growth, development and survival of Hyla. However, as opposed to Rana, Hyla seems unaffected by the presence of the water mold, and where the parasite is abundant the outcome of the competitive interactions between the two frog species is reversed.

[9] In northern England the population dynamics of red grouse Lagopus lagopus is determined by the directly transmitted endoparasitic nematode Trichostrongylus tenuis. The nematode reduces the birds' reproductive success and may cause intensity-dependent mortality, and where the parasite is abundant, the grouse population dynamics are characterised by recurrent nematode-induced crashes. In absence of the parasite the grouse population develops more steadily. The infection intensity of $T$. tenuis is largely determined by the survival rate of the free-living larvae, which itself depends on soil moisture. Accordingly, the cyclicity of the grouse dynamic is associated with particularly high levels of precipitation that increase the survival rate of the parasite larvae and hence infection intensity in the birds. Since changes in precipitation levels are an integral part of NAO, transitions between cyclic and noncyclic population development in red grouse could be triggered by the climate oscillation in parts of the bird's distributional range.

The above overview suggests that climate oscillations can have a profound coordinated influence upon hostparasite interactions, and in turn host population and community dynamics. The magnitude of the impact of large-scale climate changes on ecosystems may not be fully understood unless weather-mediated host-parasite interactions are taken into consideration. Here, it should be emphasised that the influence of parasites can also be of a more subtle nature: parasites may determine the strength by which the population trend of a given host organism correlates with the climate oscillation. Parasitism usually acts in a host density-dependent manner, and in cases where the climate change directly favours both host and parasite, the negative influence of the parasites may tend to counter the otherwise positive effect on the increasing host population. This could result in either no or a weaker correlation with climate than otherwise expected. On the other hand, in cases where changing weather conditions inflict a small but direct (i.e. for other reasons than parasites) decline in the host population and simultaneously enhance parasite abundance, the inherently weak host population-climate relationship may become significantly stronger due to the increasing parasite abundance. Moreover, should the life-cycle processes of a given species of parasite be relatively resilient to climate changes, parasite-induced mortality could still be the ultimate factor that brings the host population down if weather conditions change to the worse: the most heavily infected and hence usually competitively inferior individuals will be the first to go. The synergistic effect of bad weather and parasitism has, for instance, been proposed to precipitate crashes in Soay sheep populations (Grenfell et al. 1998).

The impact of climate oscillations on host-parasite interactions could also be approached from the perspective of epidemiological models. The population dynamics of hosts and parasites can be described by simple differential equations, and the ability of a parasite to invade, spread and persist in a host population can be modelled using the parasite's basic reproductive rate, $R_{0}$ (Anderson and May 1978, 1982). The parameters included in these epidemiological models range from the mortality rate of parasite infective stages in the external environment, to the parasite-induced rate of host mortality. All these parameters can be influenced substantially by climatic conditions. It should be possible to incorporate knowledge of the effects of climate on epidemiological parameters into the models, to achieve forecasts of the impact of the climate oscillations on host-parasite population dynamics.

Our goal was to highlight the potential links between parasitism and climate oscillations. To date, no studies have directly considered the importance of large-scale climate fluctuations for host-parasite interactions and the potential cascading community effects. It may be worthwhile to address such complex interactions in future investigations.

Acknowledgements - We thank Mads C. Forchhammer and two referees for useful comments on an earlier draft. The work was supported The Marsden Foundation (New Zealand) and The Danish Natural Science Research Council (K. N. Mouritsen).

\section{References}

Allan, R., Lindesay, J. and Parker, D. 1996. El Niño Southern Oscillation and climate variability. - CSIRO, Collingwood.

Allison, F. R. 1979. Life cycle of Curtuteria australis n.sp. (Digenea: Echinostomatidae: Himasthlinae), intestinal parasite of the South Island pied oystercatcher. - N.Z. J. Zool. 6: 13-20

Anderson, R. C. 1992. Nematode parasites of vertebrates. Their development and transmission, 2nd ed. - CABI Publishing, New York.

Anderson, R. M. 1974. Population dynamics of the cestode Caryophyllaeus laticeps (Pallas, 1781) in the bream (Abramis brama L.). - J. Anim. Ecol. 43: 305-321.

Anderson, R. M. and May, R. M. 1978. Regulation and stability of host-parasite population interactions. I. Regulatory processes. - J. Anim. Ecol. 47: 219-247.

Anderson, R. M. and May, R. M. 1982. Coevolution of hosts and parasites. - Parasitology 85: 411-426.

Ataev, G. L. 1991. Temperature influence on the development and biology of redia and cercariae of Philophthalmus rhionica (Trematoda) (in Russian). - Parazitologiya 25: 349359.

Ansell, A. D. 2001. Dynamics of aggregations of a gastropod predator/scavenger on a New Zealand harbour beach. - J. Moll. Stud. 67: 329-341. 
Boag, B. and Neilson, R. 1996. Effects of potential climatic changes on plant-parasitic nematodes. - Aspects Appl Biol. 45: 331-334.

Boulinier, T. and Danchin, E. 1996. Population trends in kittiwake Rissa tridactyla colonies in relation to tick infestation. - Ibis 138: 326-334.

Campbell, A. and Glines, M. V. 1979. Development, survival, and oviposition of the rabbit tick, Haemophysalis leporispalustris (Packard) (Acari: Ixodidae), at constant temperatures. - J. Parasitol. 65: 777-782.

Chilton, N. B., Andrews, R. H. and Michael, C. 2000. Influence of temperature and relative humidity on the moulting success of Amblyomma limbatum and Aponomma hydrosauri (Acari: Ixodidae) larvae and nymphs. - Int. J. Parasitol. 30: 973-979.

Chubb, J. C. 1980. Seasonal occurrence of helminths in freshwater fishes. Part III. Larval Cestoda and $\mathrm{Ne}$ matoda. - Adv. Parasitol. 18: 1-120.

Chubb, J. C. 1982. Seasonal occurrence of helminths in freshwater fishes. Part IV. Adult Cestoda, Nematoda and Acanthocephala. - Adv. Parasitol. 20: 1-292.

De, N. C., Sinha, R. K. and Majumdar, G. 1986. Larval development of Procamallanus spiculogubernaculus Agarwal, 1958 (Nematoda: Camallanidae) in copepods. - Folia Parasitol. 33: 51-60.

Duffy, D. C. 1983. The ecology of tick parasitism on densely nesting Peruvian seabirds. - Ecology 64: 110-119.

Duffy, D. C. and Campbell, S. R. 1994. Ambient air temperature as a predictor of activity of adult Ixodes scapularis (Acari: Ixodidae). - J. Med. Entomol. 31: 178-180.

Erasmus, D. A. 1972. The biology of trematodes. - The University Press, Belfast.

Evans, N. A. 1985. The influence of environmental temperature upon transmission of the cercariae of Echinostoma liei (Digenea: Echinostomatidae). - Parasitology 90: 269275.

Ford, S. E. 1996. Range extension by the oyster parasite Perkinsus marinus into the northeastern United States: response to climate change? - J. Shellfish Res. 15: 45-56.

Ginetsinskaya, T. A. 1988. Trematodes, their life cycles, biology and evolution. - Amerind Publishing, New Delhi.

Grenfell, B. T., Wilson, K., Finkenstädt, B. F. et al. 1998. Noise and determinism in synchronized sheep dynamics. - Nature 394: 674-677.

Hagen, N. T. 1995a. Sea urchin outbreaks and epizootic disease as regulating mechanism in coastal ecosystems. In: Eleftheriou, A., Ansell, A. D. and Smith, C. J. (eds) Biology and ecology of shallow waters. Olsen \& Olsen, Fredensborg, pp. 303-308.

Hagen, N. T. 1995b. Recurrent destructive grazing of successionally immature kelp forests by green sea urchins in Vestfjorden, Northern Norway. - Mar. Ecol. Prog. Ser. 123: $95-106$.

Harvell, C. D., Kim, K., Burkholder, J. M. et al. 1999 Emerging marine diseases - climate links and anthropogenic factors. - Science 285: 1505-1510.

Harvell, D., Kim, K., Quirolo, C. et al. 2001. Coral bleaching and disease: contributors to 1998 mass mortality in Briareum asbetinum (Octocorallia, Gorgonacea). - Hydrobiologia 460: 97-104.

Hoenicke, R. 1984. The effect of a fungal infection of Diaptomus novamexicanus eggs on the zooplankton community structure of Castle Lake, California. - Verh. Internat. Verein. Limnol. 22: 573-577.

Hudson, P. and Greenman, J. 1998. Competition mediated by parasites: biological and theoretical progress. Trends Ecol. Evol. 13: 387-390.

Hudson, P. J., Dobson, A. P. and Newborn, D. 1985. Cyclic and non-cyclic populations of red grouse: a role for parasitism? - In: Rollison, D. and Anderson, R. M. (eds) Ecology and genetics of host-parasite interactions. Academic Press, pp. 77-89.
Hudson, P. J., Dobson, A. P and Newborn, D. 1998. Prevention of population cycles by parasite removal. - Science 282: 2256-2258.

Hurrell, J. W. and Van Loon, H. 1997. Decadal variation in climate associated with the North Atlantic oscillation. Clim. Change 36: 301-326.

Huxham, M., Raffaelli, D. and Pike, A. 1993. The influence of Cryptocotyle lingua (Digenean: Plathyhelminthes) infections on the survival and fecundity of Littorina littorea (Gastropoda: Prosobranchia); an ecological approach. J. Exp. Mar. Biol. Ecol 168: 223-238.

Huxham, M., Raffaelli, D. and Pike, A. 1995. Parasites and food web patterns. - J. Anim. Ecol. 64: 168-176.

Jensen, K. T. and Mouritsen, K. N. 1992. Mass mortality in two soft-bottom invertebrates, Hydrobia ulvae and Corophium volutator - the possible role of trematodes. Helgoländ. Meeresunters. 46: 329-339.

Kearn, G. C. 1986. The eggs of monogeneans. - Adv. Parasitol. 25: 175-273.

Kiesecker, J. M. and Blaustein, A. R. 1999. Pathogen reverses competition between larval amphibians. - Ecology 80: $2442-2448$.

Kiesecker, J. M., Blaustein, A. R. and Belden, L. K. 2001. Complex causes of amphibian population declines. $-\mathrm{Na}$ ture 410: 681-684.

Kim, Y. and Powell, E. N. 1998. Influence of climate change on interannual variation in population attributes of Gulf of Mexico oysters. - J. Shellfish Res. 17: 265-274.

Korotkov, Y. S. 1998. Cyclic processes in the dynamic of Ixodes persulcatus number (Acarina: Ixodidae) and their relation to weather and climatic conditions (in Russian). - Parazitologiya 32: 21-31.

Lemly, A. D. and Esch, G. W. 1984. Effects of the trematode Uvulifer ambloplitis on juvenile blugill sunfish, Lepomis macrochirus: ecological implications. - J. Parasitol. 70: 475-492

Lindgren, E., Talleklint, L. and Polfeldt, T. 2000. Impact of climate change on the northern latitude limit and population density of the disease-transmitting European tick Ixodes ricinus. - Environ. Health Perspec. 108: 119-123.

Lo, C.-T. and Lee, K.-M. 1996. Pattern of emergence and the effects of temperature and light on the emergence and survival of heterophyid cercariae (Centrocestus formosanus and Haplorchis pumilio ). - J. Parasitol. 82: 347-350.

Lyholt, H. C. K. and Buchmann, K. 1996. Diplostomum spathaceum: effect of temperature and light on cercarial shedding and infection of rainbow trout. - Dis. Aquat. Org. 25: 169-173.

McCarthy, A. M. 1999. The influence of temperature on the survival and infectivity of the cercariae Echinoparyphium recurvatum (Digenea: Echinostomatidae). - Parasitology 118: $383-388$.

Marcogliese, D. J. 2001. Implication of climate change for parasitism of animals in the aquatic environment. - Can. J. Zool. 79: 1331-1352.

Marcogliese, D. J. and Cone, D. K. 1997. Food webs: a plea for parasites. - Trends Ecol. Evol. 12: 320-325.

Minchella, D. J. and Scott, M. E. 1991. Parasitism: a cryptic determinant of animal community structure. - Trends Ecol. Evol. 6: 250-254.

Miscevic, Z., Milutinovic, M., Petrovic, Z. and Bisevac, L. 1989. The effect of macroclimatic factors on the dynamics of tick (Acarina, Ixodoidea, Ixodidae) populations in northeastern Serbia (Yugoslavia). - Acta Veterinaria 39: $241-249$.

Morand, S. and Gonzales, E. A. 1997. Is parasitism a missing ingredient in model ecosystems? - Ecol. Model. 95: $61-74$.

Mouritsen, K. N. and Madsen, J. 1994. Toxic birds: defence against parasites? - Oikos 69: 357-358.

Mouritsen, K. N. and Jensen, K. T. 1997. Parasite transmission between soft-bottom invertebrates: temperature mediated infection rates and mortality in Corophium volutator. - Mar. Ecol. Prog. Ser. 151: 123-134. 
Mouritsen, K. N., Jensen, T. and Jensen, K. T. 1997. Parasites on an intertidal Corophium-bed: factors determining the phenology of microphallid trematodes in the intermediate host population of the snail Hydrobia ulvae and the am phipod Corophium volutator. - Hydrobiologia 355: 61-70.

Mouritsen, K. N., Mouritsen, L. T. and Jensen, K. T. 1998. Change in topography and sediment characteristics on an intertidal mud-flat following mass-mortality of the amphipod Corophium volutator. - J. Mar. Biol. Ass. U.K. 78 1167-1180.

Ottersen, G., Planque, B., Belgrano, A. et al. 2001. Ecological effects of the North Atlantic Oscillation. - Oecologia 128: $1-14$.

Pechenik, J. A. and Fried, B. 1995. Effect of temperature on survival and infectivity of Echinostoma trivolis cercariae: a test of the energy limitation hypothesis. - Parasitology 111: 373-378

Pflüger, W. 1980. Experimental epidemiology of Schistosomiasis. 1. The prepatent period and cercarial production of Schistosoma mansoni in Biomphalaria snails at various constant temperatures. - Z. Parasiten. 63: 159-169.

Poulin, R. 1999. The functional importance of parasites in animal communities: many roles at many levels? - Int. J. Parasitol. 29: 903-914.

Scheibling, R. E. and Hennigar, A. W. 1997. Recurrent outbreaks of disease in sea urchins Strongylocentrotus droe bachiensis in Nova Scotia: evidence for a link with large-scale meteorological and oceanographic events. Mar. Ecol. Prog. Ser. 152: 155-165.

Shostak, A. W. and Esch, G. W. 1990. Photocycle-dependent emergence by cercariae of Halipegus occidualis from $\mathrm{He}$ lisoma anceps, with special reference to cercarial emergence patterns as adaptations for transmission. - J. Parasitol. 76: $190-195$.
Skorping, A. and Högstedt, G. 2001. Trophic cascades: a role for parasites? - Oikos 94: 191-192.

Smith, G. and Grenfell, B. T. 1985. The population biology of Ostertagia ostertagi. - Parasitol. Today 1: 76-81.

Sutherst, R. W. 1998. Implications of global change and climate variability for vector-borne diseases: generic approaches to impact assessments. - Int. J. Parasitol. 28: 935-945.

Thomas, F. and Poulin, R. 1998. Manipulation of a mollusc by a trophically transmitted parasite: convergent evolution or phylogenetic inheritance? - Parasitology 116: 431-436.

Thomas, F., Renaud, F., de Meeûs, T. and Poulin, R. 1998. Manipulation of host behaviour by parasites: ecosystem engineering in the intertidal zone? - Proc. R. Soc. Lond. B 265: $1091-1096$

Thomas, F., Poulin, R., de Meeüs, T. et al. 1999. Parasites and ecosystem engineering: what roles could they play? - Oikos 84: $167-171$

Vail, S. G. and Smith, G. 1998. Air temperature and relative humidity effects on behavioural activity of blacklegged tick (Acari: Ixodidae) nymphs in New Jersey. - J. Med. Entomol. 35: 1025-1028.

Vanoverschelde, R. 1982. Studies on the life-cycle of Himasthla militaris (Trematoda: Echinostomatidae): influence of temperature and salinity on the life-span of the miracidium and the infection of the first intermediate host, Hydrobia ventrosa. - Parasitology 84: 131-135.

Wilson, W. H., Francis, I., Ryan, K. and Davy, S. K. 2001. Temperature induction of viruses in symbiotic dinoflagelltes. - Aquat. Microb. Ecol. 25: 99-102.

Zahler, M. and Gothe, R. 1995. Effect of temperature and humidity on egg hatch, moulting and longevity of larvae and nymphs of Dermacentor reticulates (Ixodidae). - Applied Parasitol. 36: 53-65. 